\title{
The use of evocative content-section of foreign language media texts in environmental education
}

\author{
Mariya Konovalova* \\ Chelyabinsk State University, Chelyabinsk, Russia
}

\begin{abstract}
The article is devoted to the question of studying the application of a content-slice of foreign-language media texts, created on the basis of evocative representation, in order to identify relevant environmental topics and use them in the process of teaching environmental students. An analysis of the evocative representation of environmental topics in media discourse, understood as a set of media texts, made it possible to single out the most demanded and topical issues in the modern global environmental community. The content-slice used in the study was developed on a cognitive basis with a systematic study of cognitive categories and types of information concept. Cognitive categories were identified by the representation in the titles of Englishlanguage media texts of a certain type of information concept indicating the importance and frequency of its reproduction in media discourse over a certain period. The identified cognitive categories and environmental topics were used in teaching environmental students English, significantly expanding the educational horizon of students, involving them in the discussion of modern environmental problems with an orientation towards the development of their own region and finding the place of its problems in global environmental practice. When using the content-slice on media texts classified under environmental headings, the following environmental themes were identified: Danger of Hurricanes, Green Energy, Dangerous Footing; Global Warming / Climate Change / Climate Skeptic, Pesticides, Biodiversity, Wildlife, Ecology in Space, Ecological education and researches, Recycling, Emissions. With the obvious value of using this material in the classroom of environmental students, the issues of practical development of these thematic areas not only in foreign language classes, but also in specialized subjects of environmental education have great potential.
\end{abstract}

\section{Introduction}

Modern environmental education should contribute to the formation of a wide range of competencies, knowledge in the fields of biology, geology, regional studies, energy, soil science, etc. Teaching in these disciplines in Russian universities is mostly conducted in

* Corresponding author: makonovalova@yandex.ru 
Russian. The study of a foreign language in environmental education is carried out on the basis of general conversational topics that often do not cover special knowledge: acquaintance, description of people, food, healthy lifestyle, travel, the country of the target language, etc. Thus, in the process of teaching future ecologists, general linguistic competencies are formed, which do not include environmental terminology and topical issues raised in the reports of environmental state and public organizations.

This issue is presented in an accessible and concise form in a media discourse or a set of media texts when covering the events of ecological public life. The most recent articles and notes on environmental issues, most often, appear in foreign-language publications, news from which are reprinted in Russian-language media. Therefore, the use of foreign language media texts in the classroom of environmental students is extremely justified and has many advantages.

First of all, I would like to focus on the coverage in media texts of the most important environmental problems around the world, the experience of different countries in solving them, modern research and technologies used in various economic sectors within the framework of programs for the development of individual regions. The study of these media texts allows students to familiarize themselves with the most important achievements in the field of ecology in different regions of the world, as well as integrate and apply them, where possible, in their own region.

The main difficulty when referring to the English-language media texts on ecology was the selection of educational material and determination of the range of topics to be studied. Among the abundance of English-language environmental texts, it was necessary to select the most relevant and appropriate to the needs of our region. The currently proposed methods of text and discourse analysis, such as the method of continuous sampling, case study, content analysis, can be adapted to this task and applied on the specified material, however, they will not give the expected effect in terms of choosing the most relevant and promising topics that have potential for regional development. The necessary technique was found in a combination of content analysis and a media content slice, which I developed on the basis of evocative representation..

\section{Methodology}

\subsection{Evocative representation}

\subsubsection{The concept of evocative representation}

Evocation is one of the processes taking place in the Internet media discourse and represents the cognitive basis for the representation of events. For the first time in Russian science, evocation was identified by A.A. Chyvakin, who studied this phenomenon on the basis of a literary text [1]. In the monograph on the evocation of A.A. Chuvakin, following T. van Dejk, notes that the text, and the discourse, is able to give an idea of events, the totality of which, with the help of cognitive structures, represents a certain fragment of the world $[1,2]$. The actual in this case linguistic-situational communication according to A.A. Chuvakin represents in discourse only a part of situations, the rest of the information about them is conveyed by special means, including the background knowledge of the recipient of information [1]. Thus, the structure of the media text, in which one has to look for information on environmental topics for classes, is embodied by the classic formula "who, what, where, when, how much and how." 
So, evocative representation represents the process of reproducing concepts in a media discourse or a set of media texts. Reality objects are reproduced in media discourse through structures such as various types of concepts and cognitive categories. This type of functioning is characteristic of media discourse, which structures information so that an event is reflected in a certain stereotypical situation that reveals topical issues of ecology in media discourse. The title contains basic information to make it easier to find relevant media text. On the basis of the provisions of evocative representation in the Internet media discourse, a content-slice is developed, which makes it possible to identify media texts on any topic, including the environmental one $[1,2,3]$.

\subsubsection{Content slice method}

Content-slice represents the author's method of studying media content on a specific topic. Cognitive categories and types of concepts that are relevant for the selected environmental topic are collected in a matrix of collective consciousness, which makes it possible to identify and list all the topics that need to be introduced to students in the learning process, thereby forming a profile competence among the language itself [4]. Let's take a look at the components of a content slice.

The central component of the content slice is an information concept, in this case representing environmental themes in media texts. Matrix semantic components by means of cognitive structures correlate with the heading "Ecology", etc. The rubric on media sites reveals the direction of the information flow on this topic, leads to other publications that contain information concepts that represent the same cognitive structures. A rubric represents a thematic concept with one word or phrase, which is thematically included in several media texts. The names of the rubrics form a thematic series, around which peripheral concepts are grouped, leading to environmental topics, represented in other media texts $[5,6]$.

Thus, when studying the content of several news media sites for the purpose of representing topical environmental topics, the following components of the content-slice were identified: context, types of information concept (IC), cognitive categories and environmental topics of Internet media discourse. The empirical material will be analyzed in the matrix of collective consciousness structuring them according to the cognitive categories of environmental topics, represented by various types of information concept in English-language media texts.

Table 1. Matrix of collective consciousness

\begin{tabular}{|c|c|c|c|c|c|c|}
\hline IC types & $\begin{array}{c}\text { Nuclear } \\
\text { thematic }\end{array}$ & $\begin{array}{c}\text { Nuclear } \\
\text { rhematic }\end{array}$ & $\begin{array}{c}\text { Verifica- } \\
\text { tional }\end{array}$ & Peripheral & $\begin{array}{c}\text { Hypertext } \\
\text { (thematic) }\end{array}$ & $\begin{array}{c}\text { Hypertext } \\
\text { (rhematic) }\end{array}$ \\
\hline $\begin{array}{c}\text { Cognitive } \\
\text { categories } \\
\text { (Ecological } \\
\text { topics) }\end{array}$ & Headline & Headline & Headline & Headline & Headline & Headline \\
\hline
\end{tabular}

Let us consider in more detail the types of information concept presented in the matrix of collective consciousness.

\subsubsection{Types of information concept}

Nuclear information concepts are divided into two groups depending on the novelty of the information being represented.

According to the cognitive theory of N.N. Boldyrev's nuclear thematic concepts represent the knowledge accumulated in the media discourse on a specific topic [7]. Most 
often, this type of concept is represented in the title of the media text, is relevant to the covered topics, and also belongs to the core of the media discourse. In other words, the nuclear thematic concept, which is represented in the media text, is a "collapsed" knowledge about actual known information about an event or a series of events.

For example, a publication titled "How global warming is drying up the North American monsoon" explores the environmental theme of global warming using material from the North American monsoon. The representation of this topic and its relevance is indicated by the use of the phrase global warming in the title of the article, as well as detailed coverage using synonymous phrases in the media text itself: climate model, Nature Climate Change, climate predictions, knowledge of future climate, etc.

Following T.A. Vorontsova, nuclear rhematic concepts are understood as units of new knowledge with a specific content and a rigid cognitive structure, represented in a number of media texts [8]. The main component in the structure of the nuclear thematic concept is rhema, which belongs to the core of media discourse and represents a new combination of conditions, factors or objects. In contrast to the nuclear thematic concept, the rhematic concept represents new information and can determine conceptualization. For example, the headline "Modified Russian missile boosts Europe's newest environmental sentinel to space" reveals a fundamentally new environmental topic covering the application of space technologies. The novelty of this environmental topic in media discourse is due to the use of completely new technologies in a new field of human activity. Representatives of this topic are the phrases: decommissioned Russian military missile stages, satellite, satellite will measure greenhouse gases, European environmental sentinels, etc.

Verification concepts are directly related to the linguistic meaning of the truth condition according to R.V. Langacker (truth condition) [9]. R.V. Langacker understands the condition of truth as a mental comparison of meaning with reality without referring to human consciousness [10]. Verification ones also have this property, since they contain a set of features that mark the truth or falsity of the information being represented. At the same time, the consciousness of the recipient who perceives the information does not process the verification concepts, but focuses on news information.

Verification concepts are used to establish the truthfulness of information coming from the media text, regardless of the agenda of other media outlets, editorial policy of the publication, context, and author's position. That is, verification concepts verbalize knowledge that helps the recipient to establish the truth or falsity of information in the media discourse. This type of information concept allows the recipient to comprehend the differences between the represented event and its coverage in the media text. Examples of verification knowledge can be reference materials, databases, geographic, temporal, measurement data, etc.

For example, in the heading "Assumed safety of pesticide use is false, says top government scientist" and in the heading "Nomination of climate skeptic to head White House environmental office draws strong reactions." Verbalizations of verification concepts in these examples are the words and phrases safety, says top government scientist, climate skeptic, etc.

Peripheral concepts represent cognitive structures in media texts intended for orientation in media discourse. This type of information concept denotes the location of the event represented in the media text, as well as the actual topic in relation to the core of the media discourse. The core of the media discourse is represented by a set of topics or an actual agenda, which is relevant in a certain time period in the media, covering events for a large audience. In other words, the field structure of media discourse allows peripheral concepts to highlight the nuclear and peripheral topics of information flows, which is also true for environmental issues. It is this type of information concept that outlines the range of 
relevant topics and expands it through the creation of new media texts. The latter are written on the basis of peripheral concepts that represent the revealed topic with keywords.

Thus, peripheral concepts are units of knowledge that verbalize insignificant features of the events covered in media texts. For example, the media text "College of Natural Resources and Environment honors history of excellence at 25-year anniversary celebration" covers an environmental topic related to the periphery of media discourse, since the celebration of the significant date of the environmental college of one of the universities related to environmental issues, but is not globally significant.

The hypertext type of information concept correlates with the concept of hypertext. Hypertext is understood as a certain array of information that has semantic connections between the components of media texts. According to W. Kintch's theory of representation, the perception of a text is based on a certain network of interrelated propositions that create a situational model of understanding [11]. The leading role in this is played by the textual base, which represents semantic connections that are noticed by the recipient only when reading the text. The meaning of the read is supplemented by the recipient with background knowledge, which builds a situational model of understanding. So, hypertext concepts are units of knowledge that link a number of media texts into hypertext on a specific topic. Their division into thematic and rhematic ones is also determined by their belonging either to known or to new represented information.

For example, the article "General Motors to Run Ohio, Indiana Factories With $100 \%$ Wind Power" represents the environmental theme of wind energy, linking media texts with both environmental and technical issues with a hypertext concept. In this context, Wind Power represents a hypertext thematic concept. And the article "The truth about Easter Island: a sustainable society has been falsely blamed for its own demise" reveals environmental topics in the context of a tourist attraction, representing a hypertext rhematic concept.

The choice of the matrix of collective consciousness, which is understood as a set of cognitive categories, verbalized in the media discourse, for the study of environmental topics is justified by the relevance of the topics being developed. The types of information concepts, verbalized in media texts, make it possible to define cognitive categories directly related to current environmental topics. It is more expedient to use the selected topics in the course of teaching environmental students a foreign language, since their relevance for the development of core competencies is beyond doubt.

\section{Results}

The above methodology for the study of media texts was tested on the material of Englishlanguage media texts in the period from 2017 to 2019 . Approximately 500 media texts and media discourses were studied, considering and describing environmental issues in the English-language media of different countries. As a result of the selection and study of information concepts in the named empirical material, the following set of environmental topics was obtained, distributed into cognitive categories that are relevant in the collective consciousness, reflected in the Internet media discourse. So, when processing the empirical material, the following environmental topics were obtained in the English-language Internet media discourse: 
Table 2. Environmental topics in English-language media

\begin{tabular}{|c|c|c|c|c|c|c|}
\hline IC types & $\begin{array}{c}\text { Nuclear } \\
\text { thematic }\end{array}$ & $\begin{array}{l}\text { Nuclear } \\
\text { rhematic }\end{array}$ & Verifica-tional & $\begin{array}{l}\text { Peri } \\
\text { phe } \\
\text { ral }\end{array}$ & $\begin{array}{l}\text { Hypertext } \\
\text { (thematic) }\end{array}$ & $\begin{array}{l}\text { Hyper- } \\
\text { text } \\
\text { (rhema- } \\
\text { tic) } \\
\end{array}$ \\
\hline $\begin{array}{l}\text { Danger of } \\
\text { Hurricanes }\end{array}$ & & \multicolumn{2}{|c|}{$\begin{array}{l}\text { «How hurricanes such as } \\
\text { Irma and Maria can } \\
\text { devastate the Caribbean } \\
\text { marine environment» }\end{array}$} & & & \\
\hline $\begin{array}{l}\text { Green } \\
\text { Energy }\end{array}$ & $\begin{array}{l}\text { «General } \\
\text { Motors to Run } \\
\text { Ohio, Indiana } \\
\text { Factories With } \\
\text { 100\% Wind } \\
\text { Power» } \\
\end{array}$ & & & & & \\
\hline $\begin{array}{l}\text { Dangerous } \\
\text { Footing }\end{array}$ & $\begin{array}{l}\text { «Women of } \\
\text { childbea-ring } \\
\text { age around } \\
\text { world suffering } \\
\text { toxic levels of } \\
\text { mercury» }\end{array}$ & $\begin{array}{l}\text { «Hartnett- } \\
\text { Environme } \\
\text { on Danger }\end{array}$ & $\begin{array}{l}\text { White Would Put } \\
\text { t, Public Health } \\
\text { us Footing» }\end{array}$ & & & \\
\hline $\begin{array}{l}\text { Global } \\
\text { Warming/ } \\
\text { Climate } \\
\text { Change/ } \\
\text { Climate } \\
\text { Skeptic }\end{array}$ & \multicolumn{2}{|c|}{$\begin{array}{l}\text { «How global warming is } \\
\text { drying up the North } \\
\text { American monsoon» }\end{array}$} & & & & \\
\hline Pesticides & \multicolumn{2}{|c|}{$\begin{array}{l}\text { «Did Monsanto Ignore } \\
\text { Evidence Linking Its Weed } \\
\text { Killer to Cancer?» }\end{array}$} & & & & \\
\hline Biodiversity & \multicolumn{2}{|c|}{$\begin{array}{l}\text { «The Church Is Embracing } \\
\text { Biodiversity; About Time It } \\
\text { Stood For Theodiversity As } \\
\text { Well» }\end{array}$} & & & & \\
\hline Wildlife & \multicolumn{2}{|c|}{$\begin{array}{l}\text { "Utah wildlife officials want } \\
\text { to put mountain goats places } \\
\text { they haven't been since the } \\
\text { Ice Age» }\end{array}$} & & & & \\
\hline $\begin{array}{l}\text { Ecology in } \\
\text { Space }\end{array}$ & \multicolumn{2}{|c|}{$\begin{array}{l}\text { «Modified Russian missile } \\
\text { boosts Europe's newest } \\
\text { environmental sentinel to } \\
\text { space» }\end{array}$} & & & & \\
\hline $\begin{array}{l}\text { Ecological } \\
\text { education } \\
\text { and } \\
\text { researches }\end{array}$ & \multicolumn{2}{|c|}{$\begin{array}{l}\text { «Bush kids become } \\
\text { 'detectives' to save the } \\
\text { environment» }\end{array}$} & $\begin{array}{l}\text { «The Dirty } \\
\text { Secrets Saved } \\
\text { in Dead Birds' } \\
\text { Feathers» }\end{array}$ & \multicolumn{2}{|c|}{$\begin{array}{l}\text { «College of Natural } \\
\text { Resources and } \\
\text { Environ-ment honors } \\
\text { history of excellence } \\
\text { at } 25 \text {-year anniver- } \\
\text { sary celebration» }\end{array}$} & \\
\hline Recycling & & $\begin{array}{l}\text { «Why } \\
\text { Apple's } \\
\text { new } \\
\text { iPhone is } \\
\text { bad for } \\
\text { the } \\
\text { environ- } \\
\text { ment» }\end{array}$ & & & & \\
\hline
\end{tabular}




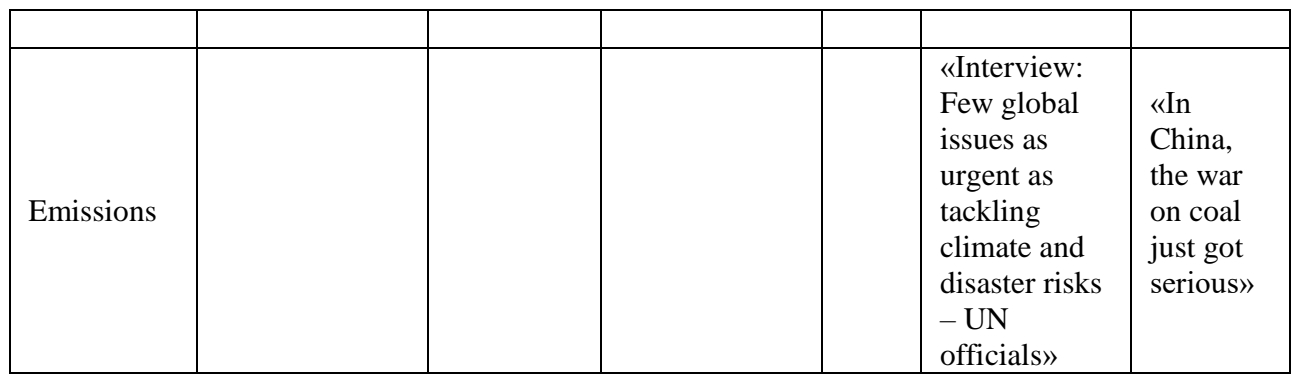

Thus, by analyzing the types of information concept, cognitive categories represented in the English-language Internet media discourse were identified, in accordance with which the following topical environmental topics were established: Danger of Hurricanes; Green Energy; Dangerous Footing; Global Warming / Climate Change / Climate Skeptic; Pesticides; Biodiversity; Wildlife; Ecology in Space; Ecological education and researches; Recycling; Emissions.

Most of the cognitive categories and themes highlighted in media texts for the specified period were represented by nuclear thematic and rhematic concepts; verification concepts often pointed to research carried out in the environmental field, and peripheral ones to significant dates and holidays in environmental organizations and educational institutions.

Hypertext thematic concepts represented environmental topics of global significance, such as climate warming, depletion of the ozone layer, increasing waste and recycling, etc. to making significant political decisions.

\section{Discussion}

The environmental themes obtained as a result of the application of the media discourse content-slice were used in the English language classes for first and second year students of the Faculty of Ecology of ChelSU. The in-depth knowledge of special subjects taught to students did not cover some of the identified environmental topics, as they are most often discussed on global public and political discussion platforms. The media borrowed this issue precisely from the socio-political discourse, which is constantly changing depending on the events taking place, however, the environmental topics raised for decades do not lose their novelty and relevance.

In particular, in the classroom, the components of problem-based learning were used in training speaking skills, such as preparing a project on the topic "What type of energy producing could not be used in the future industry of our region", "brainstorming" on "Main trends in ecological education in Ural "," A lesson in a field ", preparation of presentations on the topic" Green ecology in our region ", etc.

The study of aspects of the English language on the material of media texts selected according to the selected list of topics made it possible not only to acquaint students with modern English, but also with current environmental topics in the world, as well as with generally accepted environmental terminology in English. Preparation of students' reports on topics related to threats to humanity - "Threats to humanity" - helped to discover and trace the connection of regional environmental disasters with global environmental issues, as well as to choose the direction of scientific research for further improvement in the chosen profession. 


\section{Conclusion}

This expansion of the volume of educational materials brings the teaching of a foreign language to a new educational level and contributes to environmental education for the sustainable development of the region, where graduates who have completed this course will deal with the environment in the future.

The completed course will allow them to see the place of environmental problems of the region among environmental issues of a global scale, to find and identify possible tools and approaches to their solution, using the best practices and experience of other regions, not only their own country, but the whole world.

I believe that such a direction of teaching environmental students in a general education subject, focused on topical profile issues from fresh and reliable sources, will allow them to more deeply comprehend global environmental problems, in particular, such important and difficult for verification and solutions as global warming and climate change. determine the direction of one's own scientific research, learn how to read English-language texts on a chosen topic and, perhaps, bring your region to a new level of environmental solutions, such as, for example, environmental devices in space, environmental research in zero gravity, etc.

\section{References}

1. A. A. Chyvakin, Smeshannaya kommunikaciya v hudozhestvennom tekste (Barnaul: AltSU Publishing House, 2014)

2. T.A. van Dejk, YAzyk. Poznanie. Kommunikaciya (Typographic complex, 2000)

3. M.V. Konovalova, Evokaciya v Internet-mediadiskurse (2017)

4. M.V. Konovalova, Cogn., 71 (2015)

5. M.V. Konovalova, M.N. Latu, A.V. Razduev, EpSBS, 78, 661 (2019)

6. M.V. Konovalova, M.N. Latu, A.V. Razduev, EpSBS, 406 (2020)

7. N.N. Boldyrev, Tipy znanij i ih reprezentaciya v yazyke ("YASK", 2007)

8. T. A. Vorontsova, Rechevaya agressiya: vtorzhenie v kommunikativnoe prostranstvo (UdSU, 2006)

9. R.W. Langacker, (2000)

10. R.W. Langacker, (2006)

11. W. Kintch, T. A. van Dijk, Psychol. Rev., 85, 363 (1978) 